\title{
Knowledge and Attitude towards Antibiotic Use among College Students in Jatinangor
}

\author{
Brama Fimanggara, ${ }^{1}$ Istriati, $^{2}$ Rizki Diposarosa ${ }^{3}$ \\ ${ }^{1}$ Faculty of Medicine Universitas Padjadjaran, ${ }^{2}$ Department of Pharmacology and Therapy Faculty \\ of Medicine Universitas Padjadjaran, ${ }^{3}$ Department of Surgery Faculty of Medicine Universitas \\ Padjadjaran/Dr. Hasan Sadikin General Hospital, Bandung
}

\begin{abstract}
Background: Lack of knowledge about antibiotics cause people to have a misconception about the use of antibiotics. This may potentially lead to inappropriate use of antibiotics in the community, which is the major reason for the spread of antibiotic resistance. This study aimed to assess knowledge and attitudes toward antibiotic usage among non-medical students in Jatinangor.

Methods: This study used a cross-sectional, questionnaire based survey conducted among non-medical college students in Jatinangor, sub-district of Sumedang regency, from September to October 2013. Samples were selected using convenience sampling method, with a total number of 250 samples.

Results: More than half of the respondents (56.4\%) had a poor knowledge regarding antibiotic use. Respondents who knew that antibiotics was indicated to treat bacterial infections reached $75.2 \%$, although $58.4 \%$ of respondents still believed that antibiotics could be used in viral infection. In terms of antibiotic resistance, $72 \%$ of respondents were aware that overused of antibiotics could cause antibiotic resistance. In addition, respondents were generally found to have more positive attitudes toward antibiotics with results over $50 \%$, whereas more than one-third of the respondents wrongly self-medicated themselves with antibiotics.

Conclusions: This study reveals that most of the respondents have poor knowledge regarding antibiotics. Almost half of the respondents have a negative attitude regarding the use of antibiotics. Educational interventions are needed to promote prudent use of antibiotics among the college students. [AMJ.2016;3(2):269-74]
\end{abstract}

Keywords: Antibiotic use, attitude, Jatinangor, knowledge

\section{Introduction}

Infectious diseases are one of the major causes of death in the world. Death due to acute respiratory infection, diarrhea, measles, Acquired Immune Deficiency Syndrome (AIDS), and tuberculosis account for 85\% of all mortality from infection worldwide. ${ }^{1}$ Antibiotic is the most used drug in infection caused by bacteria. ${ }^{2}$ Currently, high intensity in irrational use of antibiotics has caused development of antibiotic resistance. It causes pathogen that cannot be cured by the same antibiotics and needs a different class of antibiotics, which makes the effectiveness of antibiotics decreases. ${ }^{3}$ Besides mortality and morbidity, antibiotic resistance also affected the economic and social aspects. According to the World Health Organization (WHO), 440.000 new cases of resistance occur each year. This issue has become a global problem and needs serious attention. ${ }^{4}$

Irrational use of antibiotics can be selfmedication by the community. Self-medication by the community has been increasingly widespread $^{4}$, and the prevalence is quite high varying between 9? ? 18\% in various European countries, ${ }^{5}$ as well as in Indonesia ${ }^{6}$ where about $16 \%$ of antibiotics is obtained without prescription. In Indonesia, uncontrolled use of antibiotics is mainly due to insufficient control on the sale, whereas the Indonesian Government restrict antibiotic availability that it could only be prescribed by a practitioner. ${ }^{7}$

People's misconception of antibiotics can

Correspondence: Brama Fimanggara, Faculty of Medicine, Universitas Padjadjaran, Jalan Raya Bandung-Sumedang Km.21, Jatinangor, Sumedang, Indonesia, Phone: +6285720383699 Email: fimanggara.brama@gmail.com 
also potentially lead to inappropriate selfmedication practice. ${ }^{8}$ This is in accordance with some studies conducted in Penang Malaysia and Yogyakarta which revealed 55\% and $49 \%$ of respondents respectively who have less knowledge about the appropriate use of antibiotics. Knowledge and beliefs are social cognitive factors that influence health-related behavior, including attitude and behavior of using antibiotics. Although knowledge itself is not sufficient to change behavior, but it plays an important role in shaping believe and attitude regarding an appropriate behavior. Reducing misconceptions regarding antibiotic use among the community members is important. ${ }^{9-10}$

Non-medical students in Jatinangor region were one of the components of the community who had high knowledge but might be less exposed to problems associated with the use of antibiotics. Additionally, they were expected to be the generation that would encourage community to have good health behavior. Thus, the study aimed to assess the current knowledge and attitudes towards antibiotic usage among non-medical students in Jatinangor, which could serve as baseline data and provided further insight in planning and developing strategies for local health education purposes.

\section{Methods}

This study was a cross-sectional survey using a validated questionnaire from previous studies and was conducted from September to October $2013 .{ }^{9}$ This study has been approved by the Health Research Ethics Commitee Faculty of Medicine, Universitas Padjadjaran. The study population was college students in Jatinangor sub-district. The confidence interval was determined at $95 \%$ with $10 \%$ of margin of error. The minimum effective sample size estimated for the survey was 97 samples. ${ }^{11}$

A total of 250 questionnaires were distributed to the respondents and samples were selected by using the convenience sampling method. The samples were eligible to be included if they lived in Jatinangor in the period of May-November 2013; were 18-23 years old; and studied in a non-medical faculty. The medical faculties are faculty of medicine, faculty of pharmacy, faculty of nursing, faculty of psychology, and faculty of dentistry. Those who did not meet any of those criteria were excluded from the study.

The distributed questionnaire was adapted from previous studies and had been modified to adjust to this study. ${ }^{9}$ The questionnaire comprised two parts. Part 1 of the questionnaire consisted of 14 statements to evaluate knowledge towards antibiotic use. Respondents were requested to choose among the three options provided: "Right", "Wrong", or "I do not know". Furthermore, eight statements concerning the respondent's attitudes toward antibiotic use were included in Part 2. A fivepoint Likert scale ranging from "Strongly Agree" to "Strongly Disagree" was used to assess the responses of respondents. Positive attitudes would imply the appropriateness of antibiotic usage. The option "Disagree" for statements 1 to 6 and "Agree" for statements 7 and 8 indicated a positive attitude. ${ }^{12}$ The respondents for the attitude domain were taken from respondents who knew antibiotics, in this case only the respondents who had chosen the correct answer for question no 1 in the knowledge domain.

Then, all data were coded, entered and analyzed using Microsoft excel 2007. For each correct answer, one point was given, and zero if it was the incorrect answer and "I do not know", with a maximum obtainable correct score of 14. Respondents with a total score of $75-100 \%$ from the maximum score were considered to have good knowledge, 56-75\% were considered to have moderate knowledge, while those with a total score of $<55 \%$ were considered to have poor knowledge.12 For the attitude domain, the maximum score was 40 and the result was divided into two categories, "positive" and "negative".

\section{Result}

This study consisted of 250 respondents, and the majority of them (55.6\%) were female.

More than half of the respondents (75.2\%) knew that antibiotics were indicated to treat bacterial infections, however, 58.4\% of respondents believed that antibiotics could be used in viral infection. Meanwhile, $62 \%$ of respondents believed that antibiotics could be used to relieve pain or inflammation, and 36.4 $\%$ of respondents agreed that antibiotics could be used to treat fever.

When asked about antibiotic resistance, $72 \%$ of respondents knew that overused of antibiotics could cause antibiotic resistance. A total of 73 respondents (29.2\%) believed stopped taking antibiotics when the symptom had improved was right, and $12 \%$ of respondents still believed that not taking a full course of antibiotics would not affect its effectiveness. 
Table 1 Knowledge of Respondent Regarding Antibiotic Use

\begin{tabular}{|c|c|c|c|}
\hline Questions & $\begin{array}{l}\text { Right } \\
\text { n (\%) }\end{array}$ & $\begin{array}{l}\text { Wrong } \\
\text { n (\%) }\end{array}$ & $\begin{array}{c}\text { I Do not Know } \\
\text { n (\%) }\end{array}$ \\
\hline $\begin{array}{l}\text { Antibiotics are medicines that can kill } \\
\text { bacteria. }\end{array}$ & $188(75.2)$ & $28(11.2)$ & $34(13.6)$ \\
\hline $\begin{array}{l}\text { Antibiotics can be used to treat viral } \\
\text { infections. }\end{array}$ & $146(58.4)$ & $57(22.8)$ & $48(19.2)$ \\
\hline Antibiotics can cure all infections. & $23(9.2)$ & $136(54.4)$ & $91(36.4)$ \\
\hline $\begin{array}{l}\text { Antibiotics are indicated to relieve pain/ } \\
\text { inflammation. }\end{array}$ & $157(62.8)$ & $55(22)$ & $38(15.2)$ \\
\hline Antibiotics are used to stop fever. & $91(36.4)$ & $95(38)$ & $64(25.6)$ \\
\hline Penicillin is an antibiotic. & $133(55.2)$ & $22(8.8)$ & $95(38)$ \\
\hline Aspirin is a new generation of antibiotic. & $51(20.4)$ & $115(46)$ & $84(33.6)$ \\
\hline Paracetamol is considered as an antibiotic. & $110(44)$ & $95(38)$ & $45(18)$ \\
\hline $\begin{array}{l}\text { Diphenhydramine / Benadryl is not an } \\
\text { antibiotic. }\end{array}$ & $49(19.6)$ & $40(16)$ & $161(64.4)$ \\
\hline $\begin{array}{l}\text { Overuse of antibiotics can cause antibiotic } \\
\text { resistance. }\end{array}$ & $180(72)$ & $20(8)$ & $50(20)$ \\
\hline Antibiotics may cause allergic reaction. & $182(72.8)$ & $10(4)$ & $58(23.2)$ \\
\hline All antibiotics do not cause side effects. & $10(4)$ & $199(79.6)$ & $41(16.4)$ \\
\hline $\begin{array}{l}\text { You can stop taking a full course of } \\
\text { antibiotics if your symptoms are } \\
\text { improving. }\end{array}$ & $73(29.2)$ & $158(63.2)$ & $19(7.6)$ \\
\hline $\begin{array}{l}\text { The effectiveness of treatment is reduced if } \\
\text { a full course of antibiotics is not completed. }\end{array}$ & $162(64.8)$ & $30(12)$ & $58(23.2)$ \\
\hline
\end{tabular}

Most of the respondents (72.8\%) were aware of the harmful effect due to antibiotic allergy. As for the identification of antibiotics, more than half of the respondents (55.2\%) could identify penicillin as an antibiotic; however $44 \%$ of respondents had a misconception regarding paracetamol which they identified as an antibiotic (Table 1)

More than half of the respondents (56.4\%) had poor knowledge regarding antibiotic use, and only $17.2 \%$ of respondents had good knowledge, and the rest (26.4\%) had moderate knowledge about antibiotic use (Table 2).

Regarding the attitude of respondents towards antibiotic use a total of 188 respondents gave the correct answer in the knowledge section (part 1). Respondents were generally found to have more positive attitudes toward antibiotics with over $50 \%$ of the results (Table 4).

Meanwhile, the respondents' answer for each statement in the attitude domain shows that more than half of the respondents (52.1\%) disagreed to stop using antibiotics when they felt better. However, $23.9 \%$ of respondents still agreed to take antibiotics when they had a common cold, $38.3 \%$ of respondents believed antibiotics would always be effective in the treatment of the same infection in the future, and $21.3 \%$ respondents agreed to take leftover

Table 2 Knowledge Level of Respondent Regarding Antibiotic Use

\begin{tabular}{lcc}
\hline \multicolumn{1}{c}{ Level of Knowledge } & Number & Percentage (\%) \\
\hline Good & 43 & 17.2 \\
Moderate & 66 & 26.4 \\
Poor & 141 & 56.4 \\
Total & 250 & 100 \\
\hline
\end{tabular}


Table 3 Attitude of Respondent Regarding Antibiotic Use

\begin{tabular}{lccccc}
\hline \multicolumn{1}{c}{ Attitude } & $\begin{array}{c}\text { Very } \\
\text { Disagree }\end{array}$ & Disagree & Not Sure & Agree & $\begin{array}{c}\text { Very } \\
\text { Agree }\end{array}$ \\
\cline { 2 - 6 } & $\mathbf{n ( \% )}$ & $\mathbf{n ~ ( \% )}$ & $\mathbf{n ~ ( \% )}$ & $\mathbf{n ~ ( \% )}$ & $\mathbf{n ~ ( \% )}$ \\
\hline $\begin{array}{l}\text { When I get a cold, I will take antibiotics to } \\
\text { help me get well more quickly. }\end{array}$ & $50(26.6)$ & $44(23.4)$ & $49(26.1)$ & $31(16.5)$ & $14(7.4)$ \\
$\begin{array}{l}\text { I expect antibiotics to be prescribed by } \\
\text { my doctor if I suffer from common cold }\end{array}$ & $65(34.6)$ & $38(20.2)$ & $42(22.3)$ & $25(13.3)$ & $18(9.6)$ \\
$\begin{array}{l}\text { symptoms. } \\
\begin{array}{l}\text { I normally stop taking antibiotics when I } \\
\text { start feeling better. }\end{array}\end{array}$ & $69(36.7)$ & $29(15.4)$ & $18(9.6)$ & $41(21.8)$ & $31(1.5)$ \\
$\begin{array}{l}\text { If my family member is sick, I usually will } \\
\text { give my antibiotics to them. }\end{array}$ & $41(21.8)$ & $52(27.7)$ & $56(29.8)$ & $26(13.8)$ & $13(6.9)$ \\
$\begin{array}{l}\text { Inormally keep antibiotic stocks at home } \\
\text { in case of emergency. }\end{array}$ & $42(22.3)$ & $36(19.1)$ & $38(20.2)$ & $49(26.1)$ & $23(12.2)$ \\
$\begin{array}{l}\text { I will use leftover antibiotics for a } \\
\text { respiratory illness. }\end{array}$ & $79(42)$ & $36(19.1)$ & $33(17.6)$ & $28(14.9)$ & $12(6.4)$ \\
$\begin{array}{l}\text { I will take antibiotics according to the } \\
\text { instruction on the label. }\end{array}$ & $9(4.8)$ & $11(5.9)$ & $31(16.5)$ & $48(25.5)$ & $89(47.3)$ \\
$\begin{array}{l}\text { I normally will look at the expiry date of } \\
\text { antibiotics before taking it. }\end{array}$ & $19(10.1)$ & $4(2.1)$ & $11(5.9)$ & $35(18.6)$ & $119(63.3)$ \\
\hline
\end{tabular}

antibiotics to treat respiratory tract infection (Table 3)

When asked about the compliance, $72.8 \%$ of respondents would take an antibiotic in accordance with the instructions on the drug label or from the doctor's prescription, and $81.9 \%$ of respondents would look to the expiration date of the antibiotics before using (Table 3).

\section{Discussion}

In this study, most of the respondents (75.2\%) had appropriate knowledge regarding antibiotic use for bacterial infection which was a little bit lower than the surveys conducted in Malaysia $^{9}(76.7 \%)$ and in Yogyakarta ${ }^{10}$ (76\%) but this proportion was higher than the study in Netherlands ${ }^{13}(44.6 \%)$. It means, the public in general already knew the indication of antibiotics, but they knew less about the appropriate use of antibiotics as it was proven in this study.

In general (56.4\%), respondents had poor knowledge regarding antibiotic use, this was different with the survey conducted in Yogyakarta ${ }^{10}$ which shows that most participants had moderate to adequate knowledge regarding antibiotic use. This issue could be taken as our concern because many students who studied in a non-medical faculty received no further instructions on this topic and they were less exposed to the problems of antibiotics.

The misconceptions regarding the indications of antibiotic use, whether bacterial or viral infections seen in this study conformed to other reports in other literatures. The findings showed that the study population was more knowledgeable regarding the indication of antibiotics for the treatment of viral infections. The proportion of respondents

Table 4 Attitude of Respondent Regarding Antibiotic Use

\begin{tabular}{|c|c|c|}
\hline Attitude & Number & Percentage (\%) \\
\hline Positive & 100 & 53.2 \\
\hline Negative & 88 & 46.8 \\
\hline Total & 188 & 100 \\
\hline Total & 250 & 100 \\
\hline
\end{tabular}


who thought that antibiotics were effective for viral infections (58.4\%) was comparable with a survey conducted in Penang, Malaysia ${ }^{9}$ and in Yogyakarta, Indonesia, ${ }^{10}$ but was higher than proportions reported from Jordan. ${ }^{14}$ "The possible reason for inadequacy of knowledge in this area could be due to the term germ, which was normally used by general practitioners or medical staff during medical advice to the public instead of using the microbiological term bacteria or virus". ${ }^{9}$

It was found that the respondents generally lacked the knowledge to differentiate between antibiotics and other commonly used medicines. Although more than half of the respondents $(55.2 \%)$ could identify penicillin as an antibiotic but $44 \%$ of respondents thought that paracetamol is an antibiotic, which was higher than the proportion reported from Penang, Malaysia. ${ }^{9}$ This problem could be caused by several factors, the respondents might be more familiar with trade names than the drug's generic name, due to the lack of information from health care providers as well as from general practitioners.

In the present study $36.4 \%$ of respondents believed that antibiotics was used to stop fever, which was comparable with a survey conducted in Yogyakarta, Indonesia ${ }^{10}$ and also in Penang, Malaysia. ${ }^{9}$ This study revealed that $62.8 \%$ of respondents believed that antibiotics could be used to relieve pain which was close with the survey conducted in New Zealand ${ }^{15}$ $(66 \%)$.

Furthermore, most of the respondents $(63.2 \%)$ had correct knowledge of the need to take the full course of antibiotics when symptoms were improving which was higher than the study conducted in Jordan ${ }^{14}(40 \%)$. But it was different from their attitude which showed only $52.1 \%$ agreed that they would continue the medication although the symptoms were improving. Therefore, the fact shows that respondents who knew the need to take complete medication of antibiotics did not practice it. This showed that respondents did not completely understand why they needed to take the full course of antibiotics.

This study also revealed that $24.4 \%$ of respondents agreed that antibiotics could treat common cold which had lower proportion than surveys conducted in Jordan ${ }^{14}$, Turkey ${ }^{16}$, and New York. ${ }^{17}$ Frequent misuses of antibiotics to treat viral infections which were actually cured by self-medication practice would increase the risk factor of antibiotic resistance.

The uncontrolled use of antibiotics is a well-established reason for antibiotic resistance ${ }^{1,3}$ Interestingly, from this study most of the respondents (72\%) knew that overused of antibiotics could lead to antibiotic resistance, this finding was comparable with a survey in Portugal $^{8}$ which reported that $70 \%$ of respondents knew that inappropriate use of antibiotics could lead to antibiotic resistance, and which was also comparable with a survey in Yogyakarta. ${ }^{10}$ In contrast, a study in New Zealand ${ }^{15}$ showed just a few (8\%) respondents were aware that misused of antibiotics could cause resistance.

This study showed $38.3 \%$ of respondents believed antibiotics would always be effective in the treatment of thesame infection in the future. Based on a study in Jordan, the possible reason for this statement was their experience on the efficacy of previous treatment. ${ }^{18}$ Meanwhile, $21.3 \%$ of respondents agreed to take leftover antibiotics to treat upper respiratory tract infection. Leftover antibiotics might be available because of the over-prescription from the doctor or noncompliance of the respondent to complete the treatment. So, it is necessary for physicians to give prescription with the right dosage and also tell the patient to take a full course of treatment and not to use the leftover antibiotics. ${ }^{19}$

Moreover, inadequate control over the distribution and sale of antibiotics might contribute to inappropriate antibiotic use. This occurred in several studies, which indicated that antibiotics could be obtained without a prescription at both a pharmacy or over the counter (OTC). ${ }^{20}$ Antibiotic use without prescription will not only cause resistance but also have another impact such as, adverse effect of the drugs, and high cost of treatment. This means that although the respondents knew the dangers of improper use of antibiotics, they still buy antibiotics without a prescription. Another possible factor that could explain self-medication is the economic aspect, that is to save the clinicians fees. ${ }^{15}$ This fits with another study conducted by Buke et al. ${ }^{16}$ which stated that knowledge regarding antibiotic usage cannot be evaluated alone since it is not always correlated with behavior.

This study had some limitations. It used convenience sampling, therefore the results couldnot represent the population. Another limitation was this study had limited time allocation which was only one to two months to collect data.

In conclusion, this study reveals that most of the respondents have poor knowledge 
regarding antibiotic use but are still aware of its consequences, such as allergy and resistance. Almost half of the respondents have poor attitude regarding antibiotic use. Therefore, it is necessary to educate the residents of Jatinangor about the worldwide existing problems of antibiotic resistance. Further educational interventions are needed to promote prudent use of antibiotics among the college students and also to improve their understanding and perceptions on antibiotic resistance as well as their attitude towards antibiotic use in Jatinangor area.

\section{References}

1. Bhanwra S. A study of non-prescription usage of antibiotics in the upper respiratory tract infections in the urban population. J Pharmacol Pharmacother. 2013;4(1):62-4.

2. Goosens H, Ferech M, Stichele VR, Elseviers M. Outpatient antibiotic use in Europe and association with resistance: a crossnational database study. Emerg infect Dis.2005;365(9459):579-87.

3. Chambers, HF. Beta-lactam antibiotics and other inhibitors of cell wall synthesis. In: Katzung BG. Basic and clinical pharmacology. $8^{\text {th }}$ Ed. New York: Lange Medical Books/McGraw-Hill; 2001.p.75473.

4. WHO. Media centre: antimicrobial resistance. 2012.[cited 2013 June 10]. Available from: http://www.who.int/ mediacentre/factsheets/fs194/en/.

5. Grigoryan L, Haaijer-Ruskamp FM, Burgerhof JG, Mechtler R, Deschepper R, Tambic-Andrasevic A, et al. Self-medication with antimicrobial drugs in Europe. Emerg Infect Dis. 2006. 12(3):452-9.

6. Hadi U, Broek PVD, Kolopaking EP, Zairina N, Gardjito W, Gyssens IC. Cross-sectional study of availability and pharmaceutical quality of antibiotics requested with or without prescription (Over The Counter) in Surabaya, Indonesia. BMC. 2010;10:203.

7. Byarugaba DK. A view on antimicrobial resistance in developing countries and responsible risk factors. Int J Antimicrob Agents. 2004;24(2):105-10.

8. Azevedo M M, Pinheiro C, Yaphe J, Baltazar F. Portuguese students' knowledge of antibiotics: a cross-sectional study of secondary school and university students in Braga. BMC. 2009;9:359

9. Oh AL, Hassali MA, Al-Haddad MS, Sulaiman SA, Shafie AA, Awaisu A. Public knowledge and attitudes towards antibiotic usage: a cross-sectional study among the general public in the state of Penang, Malaysia. J Infect Dev Ctries. 2011;28;5(5):338-47.

10. Widayati A, Suryawati S, Crespigny CD, Hiller JE. Knowledge and beliefs about antibiotics among people in Yogyakarta City Indonesia: a cross sectional population-based survey. Antimicrob Resist Infect Control. 2012;1(1):38

11. Dahlan MS. Statistik untuk kedokteran dan kesehatan. $4^{\text {th }}$ ed. Jakarta: Salemba Medika; 2009.

12. Wawan A, Dewi M. Teori dan pengukuran pengetahuan, sikap dan perilaku manusia. Yogyakarta: Nuha Medika; 2010. p. 3-99.

13. Cals JWL, Boumans D, Lardinois RJ, Gonzales R, Hopstaken RM, Butler CC, et al. Public beliefs on antibiotics and respiratory tract infections: an internetbased questionnaire study. Br J Gen Pract. 2007;57(545):942-7.

14. Suaifan GARY, Shehadeh M, Darwish DA, Al-ijel H, Yousef AM, Darwish RM. A crosssectional study on knowledge, attitude and behaviour related to antibiotic use and resistance among medical and nonmedical university students in Jordan. J Pharm Pharmacol. 2012;6(10):763-70.

15. Norris P, Churchward M, Fa'alau F, Va'al C. Understanding and use of antibiotics amongst Samoan people in New Zealand. Journal Primary Health Care. 2009;10(3):112-9.

16. Buke C, Hosgor-Limoncu M, Ermertcan $S$, Ciceklioglu $M$, Tuncel $M$, Köse $T$, et al. Irrational use of antibiotics among university students. J Infact. 2005;51(2):135-9.

17. Jodi VE, Marcus R, Hadler JL, Imhoff $B$, Vugia DJ, Cieslak PR, et al. Consumer Attitudes and Use of Antibiotics. Emerg Infect Dis. 2003;9(9):1128-35.

18. Al-Azzam SL, Al-HUsein BA, Alzoubi F Masadeh MM, Al-horani MA. Selfmedication with antibiotics in Jordanian population. Int J Occup Med Environ Health. 2007;20(4):373-80.

19. Cliodna AM, Boyle P, Nichols T, Clappison DP, Davey P. Antimicrobial drugs in the home,United Kingdom. Emerg Infect Dis. 2006;12(10):1523-6.

20. Toogobaatar G, Ikeda N, Ali M, Sonomjamts M, Dashdemberel S, Mori R, et al. Survey of non-prescribed use of antibiotics for children in an urban community in Mongolia. Bull World Health Organ. 2010; 88(12):930-6. 